\title{
ROUSSEAU E MAQUIAVEL, PENSADORES REPUBLICANOS
}

\author{
ROUSSEAU AND MACHIAVELLI, REPUBLICAN THINKERS \\ ROUSSEAU Y MAQUIAVELO, PENSADORES REPUBLICANOS
}

\author{
Renato Moscateli \\ Doutor em Filosofia pela Unicamp. Professor da Faculdade de Filosofia da UFG. \\ rmoscateli@hotmail.com
}

\begin{abstract}
RESUMO: O tema da república é um eixo fundamental em torno do qual Nicolau Maquiavel e Jean-Jacques Rousseau desenvolveram suas respectivas reflexões sobre a política, sendo que as obras do escritor florentino serviram de referência para o filósofo de Genebra em diversos momentos. Assim, pretendo abordar algumas das questões chaves que justificam o título de pensadores republicanos atribuído a ambos os autores, enfocando o elo que eles estabeleceram entre a liberdade política e vida cívica possíveis de serem experimentadas somente pelos homens que são membros de uma república bem ordenada. Nesse regime, os indivíduos encontrariam as condições sociais apropriadas para moldar suas identidades de forma a adquirirem a virtude cívica necessária a levá-los a desejarem o bem comum em vez de apenas almejarem seus interesses particulares. Para que isso seja possível, Maquiavel e Rousseau destacaram a importância do trabalho realizado pelos legisladores, sobretudo na fundação dos Estados, quando o estabelecimento de boas instituições políticas requer o recurso à religião para obter o consentimento do povo às leis.
\end{abstract}

PALAVRAS-CHAVE: Rousseau. Maquiavel. República. Legislador. Liberdade civil. Conflitos políticos.

ABSTRACT: The theme of the republic is a fundamental axis around which Niccolò Machiavelli and Jean-Jacques Rousseau developed their respective reflections on politics, and the works of the Florentine writer served as reference for the philosopher of Geneva at several times. Thus, I intend to address some of the key issues that justify the title of republican thinkers attributed to both authors, by focusing on the link they established between the political freedom and the civic life experienced only by men who are members of a well-ordered republic. In this regime, individuals find the appropriate social conditions for shaping their identities in order to acquire the civic virtue necessary to lead them to desire the common good rather than just searching for their private interests. To ensure that to be possible, both Machiavelli and Rousseau emphasized the importance of the work done by legislators, especially in the foundation of the State, when the establishment of good political institutions requires the use of religion for obtaining people's consent to laws.

KEYWORDS: Rousseau. Machiavelli. Republic. Legislator. Civil liberty. Political conflicts.

RESUMEN: El tema de la república es un eje fundamental en torno al cual Nicolás Maquiavelo y Jean-Jacques Rousseau desarrollaron sus respectivas reflexiones sobre la política, y las obras del escritor florentino sirvieron como referencia para el filósofo de Ginebra en varias ocasiones. Por lo tanto, tengo la intención de abordar algunas de las cuestiones fundamentales que justifican el título de pensadores republicanos asignado a ambos los autores, centrándome en la conéxion que ellos establecieron entre la libertad política y la vida cívica que puede ser experimentada sólo por los hombres que son miembros de una república bien ordenada. En este régimen, las personas encuentran las condiciones sociales adecuadas a la formación de su identidad con el fin de adquirir la virtud cívica necesaria para llevarlos a desear el bien común y no sólo para buscar sus intereses privados. Para que esto sea posible, Maquiavelo y Rousseau destacaron la importancia de la labor realizada por los legisladores, sobre todo en la fundación del Estado, cuando el establecimiento de buenas instituciones políticas requiere el uso de la religión para que las leyes tengan lo consentimiento del pueblo.

PALABRAS CLAVE: Rousseau. Maquiavelo. República. Legislador. Libertad civil. Conflictos políticos.

Artigo recebido em setembro de 2015

Aprovado em novembro de 2015

Cad. Pes., São Luís, v. 22, n. Especial, set./dez. 2015 
O tema da república é um eixo fundamental em torno do qual Nicolau Maquiavel e Jean-Jacques Rousseau desenvolveram suas respectivas reflexões sobre a política, sendo que as obras do escritor florentino serviram de referência para o filósofo de Genebra em diversos momentos. Assim, pretendo abordar algumas das questões chaves que justificam o título de pensadores republicanos atribuído a ambos os autores, enfocando o elo que eles estabeleceram entre a liberdade política e vida cívica possíveis de serem experimentadas somente pelos homens que são membros de uma república bem ordenada. Certamente, uma aproximação como essa não deve desconsiderar as diferenças significativas nas teses de Maquiavel e de Rousseau, tanto do ponto de vista das ideias propriamente ditas quanto do método que eles empregaram para elaborá-las. A esse respeito, Maurizio Viroli ressalta que embora eles falem a mesma linguagem republicana:

Para Maquiavel, o problema não é justificar a existência da república, mas descobrir como ela pode ser realizada concretamente, ao passo que Rousseau [...] está preocupado, primordialmente, em fornecer uma justificação teórica para a república [...]. Maquiavel e Rousseau escrevem ambos de dentro da tradição do republicanismo moderno e abraçaram a ideia clássica da política como arte de fundar e preservar uma república. Todavia, os estilos de republicanismo que eles esposaram não foram completamente iguais, e as diferenças nos tons de seus escritos sobre o tema da república revelam uma mudança significativa dentro da linguagem do republicanismo e lançam luz sobre os problemas enfrentados pela política republicana. (VIROLI, 2002, p. 11-12, tradução nossa).

No intuito de confrontar as doutrinas dos dois autores, um primeiro ponto que merece ser destacado é a própria concepção que eles nutriram sobre o material básico da composição do corpo político, ou seja, o ser humano. Quanto a Maquiavel, em diversos momentos de suas obras vemos advertências levantadas contra a maldade presente nos homens, sendo isso um dado que os instituidores de repúblicas e os governantes jamais deveriam esquecer. Nos Discursos sobre a primeira década de Tito Lívio, lemos que a experiência histórica ensina aos legisladores que eles têm de partir do pressuposto de que "todos os homens são maus [rei] e que usarão a malignidade de seu ânimo sempre que para tanto tiverem ocasião” (MAQUIAVEL, 2007, p. 20)1. É a predominância dessa característica que explica o conselho dado por Maquiavel em O Príncipe aos governantes para que quebrem a palavra dada quando as circunstâncias mostrarem ser essa a conduta mais conveniente: "se os homens fossem todos bons, este preceito não seria bom: mas porque os homens são maus e não a observariam contigo, tu, então, não tens que observar a palavra dada para com eles" (MAQUIAVEL, 2011, p. 171)². Algumas páginas à frente, Maquiavel fornece uma descrição ainda mais detalhada do comportamento dos homens, os quais:

Geralmente são ingratos, volúveis, simuladores e dissimuladores, esquivos aos perigos, cobiçosos de ganhos; e enquanto os beneficias, são todos teus, oferecem o sangue, os bens, a vida, os filhos, [...] quando a necessidade está longe: mas, quando ela se avizinha de ti, revoltam-se, e aquele príncipe que está todo fundado em suas palavras, encontrandose desprovido de outra predisposição, arruína-se (MAQUIAVEL, 2011, p. 163)³.

Tais observações são coerentes com o núcleo da proposta metodológica do escritor florentino. Como ele afirma em O Príncipe, para escrever algo útil a quem se interessa pelas questões políticas, é preciso investigar "a verdade efetiva" das coisas e não como elas são imaginadas. Desse

\footnotetext{
${ }_{1}$ Primeira parte, capítulo 3.

2 O Príncipe, capítulo 15.

${ }^{3}$ O Príncipe, capítulo 17.
} 
modo, ele pretende se distinguir dos autores que conceberam repúblicas e principados ideais que jamais vieram a existir, uma vez que, dada a enorme diferença entre como os homens vivem e como se considera que deveriam viver, o meio mais certo de se arruinar é fechar os olhos para a realidade das práticas políticas e se perder em especulações sobre modelos perfeitos de Estado.

Se por um lado Maquiavel recomenda prudência aos legisladores, diante da suposta maldade humana, para que os ordenamentos políticos sejam sólidos, por outro, isso não significa que esses ordenamentos não possam, em grande medida, direcionar o comportamento dos homens para fins que ultrapassem a estreiteza dos interesses pessoais. Afinal, a maldade salientada pelo autor parece vir justamente do fechamento do indivíduo em torno de seus próprios desejos, o qual o leva a agir de maneira egoísta e antagônica aos demais ${ }^{4}$, vendo-os como simples meios ou obstáculos aos seus objetivos. Considerando a perspectiva de Maquiavel, Newton Bignotto (2008, p. 93-94) comenta:

Olhados em sua particularidade, os homens são timoratos e frágeis. Temem a morte e não estão dispostos, em geral, a praticar grandes ações, para alcançar a glória, ou até mesmo para aumentar seu poder. O comportamento normal dos homens é apenas medíocre e não serve como uma demonstração da presença do mal em sua natureza. Com essa observação, nosso autor escapa do universo medieval com sua insistência na queda, mas também afasta-se do elogio constante dos homens, que foi importante para a antropologia renascentista. O retrato de uma natureza errática vai assim ocupando o lugar de uma natureza má, cujos objetivos precisos seriam almejados ao longo de um combate mortal entre forças opostas. ${ }^{5}$

Portanto, caso haja condições apropriadas para retirar os homens de sua estreiteza moral, os resultados podem ser muito interessantes. Nos Discursos, Maquiavel (2007, p. 20) ressalta que:

Os homens nunca fazem bem algum, a não ser por necessidade; mas, onde são muitas as possibilidades de escolha e se pode usar da licença, tudo logo se enche de confusão e desordem. Por isso se diz que a fome e a pobreza tornam os homens industriosos, e que as leis os tornam bons.

O próprio exemplo da república romana, longamente analisado na obra, é a comprovação que Maquiavel oferece da possibilidade de formar cidadãos movidos por um admirável zelo patriótico, pois a experiência da vida livre sob esse regime político é capaz de educá-los para buscar o bem comum e lutar corajosamente em nome dele. Nesse sentido, as boas leis e os bons costumes,

\footnotetext{
${ }^{4}$ Segundo José Luiz Ames (2008, p. 140), "Para Maquiavel, o homem é determinado, fundamentalmente, pelo dinamismo da necessidade natural do desejo que o impulsiona incansavelmente e sem qualquer controle interno. A característica essencial do desejo humano é sua imoderação e desmedida. O homem é insaciável, seu desejo se dirige a tudo e sem qualquer controle interno."

${ }^{5}$ Há um trecho interessante dos Discursos (Primeira Parte, capítulo 27) em que o próprio Maquiavel relativiza a predominância da maldade no ser humano. Após descrever a recusa de Giovampagolo Baglioni de aproveitar uma excelente oportunidade para se beneficiar aprisionando o papa quando este estava à sua mercê, recusa que parecia contraditória com o mau caráter amplamente conhecido de Giovampagolo, Maquiavel (2007, p. 90) escreve: "conclui-se que os homens não sabem ser maus com honra nem bons com perfeição, e que, quando uma maldade tem em si grandeza ou é parcialmente generosa, eles não sabem praticá-la." Diante disso, propõe Newton Bignotto (2008, p. 93), "a dificuldade em descrever corretamente o ser humano vem do fato que em geral não somos nem muito bons e nem muito maus. Cada um de nós hesita numa condição intermediária, na qual a variedade de nossos sentimentos, desejos, e medos, faz com que tenhamos um comportamento errático, que torna quase impossível saber como reagiremos em cada situação."
} 
juntamente com o apoio de uma religião voltada para a exaltação do civismo, tal como a da Roma antiga, podem domar os maus impulsos e as tendências egoístas ${ }^{6}$, não para extirpá-los definitivamente, mas para inspirar nos indivíduos a virtù republicana necessária à conservação da comunidade ${ }^{7}$.

Acerca dessa virtù ${ }^{8}$, cabe dizer que se trata de um conceito fundamental e difícil de ser definido univocamente nas obras do pensador florentino. Se em O Príncipe Maquiavel havia ligado esse atributo aos grandes líderes políticos e militares, como capacidade de fazer frente aos desafios da fortuna ${ }^{9}$ por meio das qualidades apropriadas à conquista e à manutenção do poder, nos Discursos o autor nos mostra que o regime republicano demanda que os cidadãos em geral possuam a virtù, aí entendida como a firme disposição para contribuir com o bom ordenamento e a salvaguarda do corpo político, até mesmo dando a vida para proteger a liberdade da república se necessário. Diante desse nobre objetivo, assevera Maquiavel (2007, p. 443) ${ }^{10}$, os cidadãos devem fazer tudo o quer estiver ao seu alcance:

Porque, quando se delibera sobre a salvação da pátria, não se deve fazer consideração alguma sobre o que é justo ou injusto, piedoso ou cruel, louvável ou ignominioso; ao contrário, desprezando-se qualquer outra consideração, deve-se adotar a medida que the salve a vida e mantenha a liberdade.

Diante disso, John Pocock (2008) afirma que, na perspectiva maquiaveliana, as repúblicas possuem a vantagem de mobilizar mais virtù do que os principados, e o fato de integrarem uma pluralidade de sujeitos na vida pública faz com que elas sejam mais flexíveis e adaptáveis às mudanças da fortuna do que se poderia esperar da personalidade única de um indivíduo reinante.

\footnotetext{
${ }^{6}$ Ver os Discursos, Primeira Parte, capítulo 18: "Porque, assim como os bons costumes precisam de boas leis para manter-se, também as leis, para serem observadas, precisam de bons costumes. Além disso, as ordenações e leis criadas em uma república nascente, quando os homens ainda eram bons, mais tarde deixam de convir, quando eles se tornam malvados" (MAQUIAVEL, 2007, p. 72)

${ }^{7}$ Sobre os temas da educação e da religião na visão de Maquiavel, ver Ames (2006, 2008).

${ }^{8}$ Seguindo a opção de grande parte dos estudiosos de Maquiavel, mantenho no original italiano o termo virtù em vez de traduzi-lo como virtude, a fim de demarcar a diferença entre essa qualidade política louvada pelo florentino e outras modalidades de virtude moral, tal como a cristã, por exemplo.

${ }^{9}$ Ao retomar a figura da deusa Fortuna, cultuada pelos romanos na Antiguidade como a divindade responsável pela sorte (boa ou má) que atingia os indivíduos e os povos, Maquiavel certamente não está aderindo a uma visão providencialista da história, mas sim empregando a figura da fortuna para se referir ao conjunto de fatores que escapa ao controle humano e cujos desafios têm de ser enfrentados no âmbito da ação política (ver O Príncipe, capítulo 25). Desse modo, ele procura dar um peso adequado a esses elementos imponderáveis, por um lado, sem desmerecer o papel do livre arbítrio, por outro. O autor afirma julgar "ser verdadeiro que a fortuna seja árbitra de metade das nossas ações, mas que ela ainda nos deixa governar a outra metade, ou quase" (MAQUIAVEL, 2011, p. 237).

${ }^{10}$ Discursos, Terceira Parte, capítulo 41. Esta citação mostra claramente que, para Maquiavel, a discussão da bondade ligada à virtù dos cidadãos não tem um teor moralista. Longe disso, quando afirma que as leis de uma república bem-ordenada tornam os homens bons, o autor está enfatizando uma qualidade de cunho político, isto é, uma capacidade de ação dos cidadãos em defesa da pátria e do bem comum configurado na própria república e em sua liberdade (ver ADVERSE, 2007). Portanto, tais homens devem ser bons naquilo que tange à preservação do corpo político do qual fazem parte, ainda que isso exija deles, em certos momentos, condutas que poderiam ser moralmente condenáveis. Tais ideias são comparáveis àquelas expostas em O Príncipe, quando, referindo-se à virtù do governante, Maquiavel (2011, p. 271) aconselha ser "necessário que ele tenha um ânimo disposto a mudar segundo o que lhe ordenem os ventos da fortuna e as variações das coisas exigirem; e, [...] podendo, não separar-se do bem, mas, se necessário, saber praticar o mal. [...] Faça tudo, portanto, um príncipe para vencer e conservar o estado: os meios serão sempre julgados honrosos e por todos serão louvados, porque o vulgo se deixa levar por aquilo que parece e pelo resultado das coisas."
} 
Consequentemente, a guarda da liberdade pode se transformar em um desejo poderoso para os cidadãos das repúblicas. Quentin Skinner propõe que, conforme se pode depreender da leitura dos Discursos, Maquiavel concebe que há essa liberdade quando o Estado, internamente, não está sujeito à servidão política imposta por um tirano e, externamente, não se encontra sob o domínio de um poder imperial. Nessas condições, ele "se mantém independente de qualquer autoridade que não seja a da própria comunidade. Assim, a liberdade acaba por se identificar com o autogoverno" (SKINNER, 1988, p. 84). Essa experiência política do vivere libero é algo que deixa uma marca muito profunda nos cidadãos ao longo das gerações, como o florentino reconhece ao enumerar as enormes dificuldades que os conquistadores encontram para consolidar seu regime principesco sobre cidades que estavam acostumadas a se conduzir por suas próprias leis e em liberdade ${ }^{11}$. Nesse sentido, Maquiavel aponta que um dos principais obstáculos às vitórias militares dos romanos era o amor à liberdade nutrido pelos povos com os quais eles se defrontavam. Ele opõe esse desejo de liberdade ao desprezo pelo governo monárquico, então identificado com a servidão. Para o autor, era fácil entender a origem dessa afeição pela vida livre, pois "a experiência mostra que as cidades nunca crescem em domínio nem em riquezas, a não ser quando são livres" (MAQUIAVEL, 2007, p. 186-187) ${ }^{12}$. Como é a busca do bem comum que produz a grandeza de uma cidade, as repúblicas têm maiores chances de alcançá-la, pois elas representam o tipo de ordenamento civil no qual esse bem é mais valorizado. Por outro lado, o bem individual do governante costuma prevalecer nos principados, "onde, no mais das vezes, o que é feito em favor do príncipe prejudica a cidade, e o que é feito em favor da cidade o prejudica" (MAQUIAVEL, 2007, p. 187).

No regime republicano, a liberdade é um grande estímulo para a prosperidade, pois os cidadãos sabem que podem se multiplicar sem medo de que seus filhos serão escravizados, e que terão condições de desfrutar dos resultados de suas atividades produtivas. Nesse contexto, há espaço para o exercício adequado das ambições públicas e privadas ${ }^{13}$, pois, como veremos mais adiante, os conflitos motivados por diferentes desejos continuarão existindo mesmo na cidade mais bem ordenada, mas Maquiavel pensa ser viável um quadro sociopolítico no qual eles se manifestarão de um modo favorável à própria liberdade da república.

Após essas considerações iniciais sobre as ideias de Maquiavel, podemos passar agora à concepção de ser humano presente no pensamento de Rousseau e às consequências políticas que dela decorrem. Ao fazer isso, será que encontraremos uma oposição radical à visão maquiaveliana, dada a imagem tão difundida que retrata o genebrino como um apologista da bondade natural do homem? Responder a isso exige olhar com bastante cuidado para as palavras do filósofo. Há um trecho do Discurso sobre a origem da desigualdade ${ }^{14}$ que sintetiza muito bem as ideias de Rousseau (2003, p. 202, tradução nossa) ${ }^{15}$ e que vale a pena ser citado:

Os homens são maus; uma triste e contínua experiência dispensa a comprovação; entretanto, o homem é naturalmente bom, eu creio tê-lo demonstrado; portanto, o que é que pode tê-lo depravado a esse ponto senão as mudanças sobrevindas em sua constituição, os progressos que ele fez, e os conhecimentos que adquiriu? Que se admire tanto quanto se quiser a sociedade humana, não será menos verdadeiro que ela leva os homens a se odiarem entre si na medida em que seus interesses se cruzam, a se prestarem mutuamente serviços aparentes e a se fazerem, de fato, todos os males imagináveis.

\footnotetext{
11 Ver O Príncipe, capítulo 5.

12 Discursos, Segunda Parte, capítulo 2.

${ }^{13}$ Sobre as vias públicas e privadas para que os cidadãos se destaquem na república, ver a História de Florença, início do livro 7.

14 Texto também conhecido como Segundo Discurso, em referência ao fato de ter sido escrito após o Discurso sobre as ciências e as artes, ambas as obras redigidas por Rousseau em resposta a questões levantadas pela Academia de Dijon.

${ }^{15}$ Nota $n^{\circ} 9$.
} 
Essa é tese central do Segundo Discurso, texto em que o autor constrói uma história conjectural com a finalidade de distinguir o que haveria de natural no ser humano e o que lhe teria sido acrescentado de artificial na sociedade. Ao analisar essa tese, percebemos que Rousseau não nega simplesmente as observações de Maquiavel sobre a maldade humana, mas as localiza no contexto social em oposição àquilo que caracterizaria a conduta natural dos indivíduos. Por natureza, não há impulsos malignos, seja do ponto de vista físico ou moral, e sim paixões - o amor de si e a piedade - que visam tanto à conservação de cada um quanto à da espécie em geral $^{16}$. Logo, aquilo que Rousseau denomina como bondade natural concerne à harmonia entre os desejos, as necessidades e as faculdades dos homens, algo que existe espontaneamente no hipotético estado de natureza, uma condição isenta de relações sociais e de juízos morais por parte daqueles que nela se encontram.

Entretanto, a narrativa conjectural do Discurso do genebrino também busca demonstrar como o comportamento humano muda radicalmente na vida em sociedade. É nela que surge uma série de novas paixões relativas - o amor próprio é a mais poderosa de todas -, bem como desejos para além das necessidades naturais. Isso não apenas aproxima os homens, mas também gera conflitos terríveis entre eles, pois se instala um descompasso entre o que eles querem e o que podem alcançar. É interessante notar que Maquiavel (2007, p. 180) ${ }^{17}$ já havia descrito esse mesmo problema:

Visto que os apetites humanos são insaciáveis, porque, tendo os homens sido dotados pela natureza do poder e da vontade de desejar todas as coisas e pela fortuna de poder conseguir poucas, o resultado é o contínuo descontentamento nas mentes humanas e o fastio das coisas possuídas.

Aqui é preciso notar que o secretário florentino trata somente do homem em sociedade, não fazendo uma distinção como a de Rousseau entre dois estados distintos - o natural e o social -, e por isso ele vê o fenômeno descrito acima como inerente à existência humana, ao passo que Rousseau o liga ao segundo desses estados. Desse modo, é na sociedade nascente que o Segundo Discurso retrata as desigualdades se acentuando à medida que os desejos artificiais se multiplicam e fazem os homens avançarem no caminho da civilização, sendo que a distinção entre ricos e pobres é um dos resultados mais funestos desse processo:

Daí começaram a nascer, segundo os vários caracteres de uns e de outros, a dominação e a servidão, ou a violência e os roubos. Os ricos, de sua parte, nem bem experimentaram o prazer de dominar, logo desdenharam todos os outros, e se servindo de seus antigos escravos para submeter novos, só pensaram em subjugar e dominar seus vizinhos, como aqueles lobos que, uma vez comendo carne humana, recusam qualquer outro alimento e só querem devorar homens. (ROUSSEAU, 2003, p. 175-176, tradução nossa).

O desdobramento dessa ambição infinita em torno da propriedade e do poder foi a instauração da autoridade política e das leis, ambas concebidas como um ardil dos ricos para garantir suas posses frente à ameaça representada pelos demais. A partir desse momento, Rousseau nos diz que a liberdade natural foi perdida para sempre e as misérias humanas só se multiplicaram.

\footnotetext{
${ }^{16}$ Segundo Rousseau, o amor de si é a paixão natural que leva o homem a buscar não apenas sua autopreservação física de um modo estrito, mas seu próprio bem estar em geral, ao passo que a piedade seria a paixão que provoca nos indivíduos um sentimento de repugnância ao sofrimento de outrem, o que os levaria a evitar causar males uns aos outros desnecessariamente.

${ }^{17}$ Discursos, Introdução da Segunda Parte.
} 
Todavia, também é necessário lembrar que, de acordo com a narrativa rousseauniana, esses fenômenos se tornaram possíveis por causa da principal faculdade distintiva da natureza humana: a perfectibilidade. É por meio dela que os horizontes mentais do homem se alargam imensamente, de modo que seu despertar acarreta consequências negativas - o alastramento dos vícios e o acirramento das desigualdades estão entre elas -, embora traga, igualmente, diversos benefícios, na medida em que os indivíduos só conseguem se elevar à plenitude de sua humanidade graças à racionalidade e à moralidade adquiridas no convívio social ${ }^{18}$. Por isso, se a experiência histórica parece comprovar a maldade dos homens, a investigação da natureza humana empreendida por Rousseau aponta para um potencial em aberto que pode ser dirigido para formas mais nobres de existência em comunidade, dentre as quais a república é, para ele, digna de inúmeros elogios ${ }^{19}$.

A cidadania republicana aparece nas obras do genebrino como uma das melhores soluções para o verdadeiro cabo de guerra que se trava no interior daqueles que vivem em sociedade, a saber, o confronto entre as inclinações e os deveres. Assim como para Maquiavel, também na concepção de Rousseau a participação em uma república dá aos indivíduos a oportunidade de transcenderam sua perspectiva egocêntrica, limitada aos interesses particulares, para substituí-la por sentimentos e valores mais amplos. Ao expor essas ideias acerca da vida republicana, a abordagem que Rousseau emprega é, em determinados momentos, bastante próxima à do escritor florentino, tal como no louvor às virtudes cívicas e militares dos espartanos e dos romanos da Antiguidade feitas no Discurso sobre as ciências e as artes, as quais são contrastadas pelo autor com a decadência física e moral que ele enxergava nos súditos das monarquias modernas. Nesse texto, Esparta é retratada como uma república de leis sábias povoada por cidadãos que pareciam semideuses se comparados ao restante da humanidade, tamanha era a elevação de sua virtude. O povo romano, por sua vez, cuja época de simplicidade e austeridade moral também é exaltada por Rousseau, ressurge nas obras seguintes do filósofo como uma fonte de modelos de cidadania republicana, a tal ponto que ele chega a enaltecê-lo "como o povo mais livre e mais poderoso da Terra" (ROUSSEAU, 2003, p. 444)20. Tais exemplos históricos eram os que mais se aproximaram do ideal de vida republicana nutrido pelo autor, e por isso ele os evoca repetidamente sempre que tem em mira a crítica da civilização de seu tempo.

No Contrato Social, por outro lado, o enfoque de Rousseau é diferente desse olhar mais voltado para a história, pois ele apresenta os princípios do direito político que servem de escala para julgar a legitimidade de qualquer Estado21, erigindo assim a república como um referencial teórico para responder à sua questão fundamental: "Encontrar uma forma de associação civil que defenda e proteja, com toda a força comum, a pessoa e os bens de cada associado, e pela qual cada um, unindo-se a todos, obedeça, entretanto, apenas a si mesmo e permaneça tão livre quanto antes" (ROUSSEAU, 2003, p. 360, tradução nossa)22. Ao colocar a convenção - pacto social - como

\footnotetext{
${ }^{18}$ É bastante conhecido o trecho do Contrato Social (livro I, capítulo 8) no qual Rousseau retrata a "notável mudança" operada no homem quando da passagem para o estado social. O autor diz que ela conduziria à aquisição de uma nova existência, não mais puramente natural, mas civil e moral, em que a justiça substituiria o instinto, a voz do dever tomaria o lugar do impulso físico, e o direito, o lugar do apetite. Ocorreria uma verdadeira transformação intelectual e ética, na qual a razão e os sentimentos se desenvolveriam de maneira considerável.

${ }^{19}$ Nesse sentido, Jean Starobinski (1991, p. 300) salienta a insólita combinação de "pessimismo histórico" e de "otimismo antropológico" no pensamento de Rousseau.

${ }^{20}$ Contrato Social, livro IV, capítulo 4.

${ }^{21}$ Ver o Emílio, livro 5: "Antes de observar, é preciso criar regras para suas observações: é preciso criar uma escala para relacionar a ela as medidas que se toma. Nossos princípios do direito político são essa escala. Nossas medidas são as leis políticas de cada país." (ROUSSEAU, 1980, p. 837, tradução nossa).

22 Contrato Social, livro I, capítulo 6.
} 
a única maneira de formar um estado civil condizente com a justiça e a liberdade, Rousseau define a república não como uma espécie de governo entre outras, mas como "todo Estado regido por leis, sob qualquer forma de administração que possa estar: pois somente então o interesse público governa, e a coisa pública é alguma coisa" (ROUSSEAU, 2003, p. 379-380, tradução nossa) ${ }^{23}$. Diferentemente daquele pacto descrito no Segundo Discurso, urdido em favor dos interesses dos ricos e para consolidar as desigualdades entre os indivíduos, o pacto concebido por Rousseau no Contrato Social busca constituir a igualdade entre os cidadãos que, conjuntamente, exerceriam o poder na qualidade de povo soberano.

Nessa obra, vemos o Estado sendo delineado como um corpo moral dotado de uma vontade geral. Essa vontade do soberano é voltada ao bem de todos os seus membros, pois se encontra na intersecção dos interesses comuns dos indivíduos, isto é, naquilo que eles desejam na condição de cidadãos. Segundo Rousseau, tal deve ser a fonte das leis republicanas, leis que tratam a todos igualmente e são a manifestação da própria liberdade civil, na medida em que cada um obedece à legislação à qual deu seu consentimento. Desse modo, o genebrino compreende que a cidadania demanda um compromisso de todos com o bem da coletividade, pois ao fazer uso do poder legislativo que lhes compete, eles precisam pensar prioritariamente naquilo que é melhor para o Estado, o que leva à necessidade da generalização da vontade no que diz respeito aos assuntos públicos.

Certamente, Rousseau tinha consciência de que atender a essa demanda não é um objetivo fácil, dado que, por natureza, cada indivíduo tende a procurar apenas seu bem particular. Por isso, ao integrar o corpo político, cada um é levado a passar por uma transformação crucial, deixando de ser uma unidade independente para se tornar parte de um todo maior cuja preservação terá de prezar tanto quanto, ou até mais que a sua própria. O responsável por dar início a essa mutação é o legislador que, nos primórdios do Estado, realiza o trabalho de "desnaturação" necessário para incutir nos homens um conteúdo moral que os liga a todos os outros membros da república. Assim, o indivíduo perde, de certo modo, suas forças próprias para receber outras "das quais ele não possa fazer uso sem o auxílio de outrem. Quanto mais essas forças naturais são mortas e aniquiladas, mais as adquiridas são grandes e duráveis, mais, também, a instituição é sólida e perfeita" (ROUSSEAU, 2003, p. 382, tradução nossa) ${ }^{24}$.

Para dar prosseguimento à obra do legislador, Rousseau propõe uma educação pública adequada à formação dos cidadãos, a qual lhes transmitirá o caráter nacional de seu povo e:

Os levará a fazer por gosto e por paixão o que jamais se faz muito bem quando não se age a não ser por dever ou por interesse. [...] Eles obedecerão às leis e não as eludirão porque elas Ihes convirão e terão o consentimento interno de sua vontade. Amando a pátria, eles a servirão por zelo e de todo o coração. (ROUSSEAU, 2003, p. 961, tradução nossa) ${ }^{25}$.

Educados dessa maneira desde a mais tenra idade, esses homens aprenderiam a ver seu bem individual como indissociável do bem comum, pois sua identificação e seu devotamento à

\footnotetext{
${ }^{23}$ Contrato Social, livro II, capítulo 6.

${ }^{24}$ Contrato Social, livro II, capítulo 7. Ver o Emílio, livro 1: "O homem natural é tudo para si: ele é a unidade numérica, o inteiro absoluto que só tem relação consigo mesmo ou com seu semelhante. O homem civil é somente uma unidade fracionária que se apoia no denominador, e cujo valor está em sua relação com o inteiro, que é o corpo social. As boas instituições sociais são aquelas que sabem melhor desnaturar o homem, subtrair sua existência absoluta para lhe dar uma relativa, e transportar o eu para a unidade comum; de modo que cada particular não se considere mais um, mas parte da unidade, e não seja mais sensível exceto no todo." (ROUSSEAU, 1980, p. 249, tradução nossa).

${ }^{25}$ Considerações sobre o governo da Polônia, capítulo 3.
} 
república sempre os guiariam no cumprimento de seus deveres. Em coerência com esse pensamento, Rousseau escreve que "A pátria não pode subsistir sem a liberdade, nem a liberdade sem a virtude" (ROUSSEAU, 2003, p. 259) ${ }^{26}$, pois cada um desses elementos está indissoluvelmente ligado àquilo que todos os cidadãos precisam valorizar e amar como partes de si mesmos.

Logo, fica perceptível que o cultivo da virtude cívica consiste em uma tarefa essencial para aqueles que são responsáveis pelo ordenamento do corpo político. Maquiavel e Rousseau deram uma atenção especial aos legisladores como aqueles que lançam os alicerces da república, estabelecendo instituições e costumes apropriados ao povo que pretendem formar. Se o trabalho desses sujeitos extraordinários for bem sucedido, o Estado conhecerá a liberdade. Caso contrário, os cidadãos terão enormes dificuldades para tentar reformar suas leis e instituições defeituosas, e a não ser que contem com o auxílio da fortuna - para usar o conceito maquiaveliano -, talvez jamais obtenham êxito. A fim de realizar sua obra, o legislador precisa ter uma ascendência reconhecida pelas pessoas sobre as quais agirá, e o caráter próprio dessa autoridade é algo em relação a que as ideias de Maquiavel e Rousseau possuem semelhanças e divergências.

Em princípio, ambos concordam no tocante ao uso da religião feito pelos legisladores com o intuito de persuadir os indivíduos a aceitarem os ordenamentos que lhes são propostos. Mencionando Numa Pompílio, nos Discursos, Maquiavel diz que o grande mérito desse monarca foi fixar uma série de ritos e crenças para fortalecer a ordem pública e a coesão social de Roma. Por considerar que sua autoridade como rei talvez não bastasse para garantir a aceitação de suas palavras, Numa teve a astúcia de atribuí-las a uma divindade, algo que Maquiavel descreve como uma prática comum em situações como essa. Para ele:

Nunca houve ordenador de leis extraordinárias, em povo nenhum, que não recorresse a Deus, porque de outra maneira elas não seriam aceitas: pois há muitas boas coisas que os homens prudentes conhecem, mas que não têm em si razões evidentes para poderem convencer os outros. Por isso, os homens sábios, que querem desembaraçar-se dessa dificuldade, recorrem a Deus. (MAQUIAVEL, 2007, p. 50) ${ }^{27}$.

Rousseau, por sua vez, repete essa tese no Contrato Social, citando inclusive a fonte. De acordo com ele, no passado mais remoto, os homens não tiveram outros reis além dos deuses, pois não conseguiam conceber a ideia de serem governados por seus semelhantes. Resultou disto que cada povo tinha seu "deus nacional". Neste contexto em que a fé e a política andavam lado a lado, o legislador era obrigado a falar a língua da religião para se fazer ouvir. Ainda que suas sábias máximas fossem o fruto de uma razão sublime, ele precisava expressá-las como se elas tivessem saído da boca dos deuses, "a fim de que os povos, submissos às leis do Estado como às da natureza, e reconhecendo o mesmo poder na formação do homem e na da cidade, obedecessem com liberdade e suportassem docilmente o jugo da felicidade pública" (ROUSSEAU, 2003, p. 383, tradução nossa) ${ }^{28}$. Assim, diz Rousseau, quando legisladores como Moisés, Numa ou

\footnotetext{
${ }^{26}$ Economia Política. Sobre a educação cívica, ver não apenas o verbete da Economia Política, mas também o capítulo 4 das Considerações sobre o governo da Polônia.

${ }^{27}$ Discursos, Primeira Parte, capítulo 11. Nesse sentido, "O fundamento da religião para Maquiavel é, pois, o medo de um Deus que, ainda que seja apresentado como algo que tem certa feição humana, considerado em si mesmo não constitui razão de obrigação política e de vínculo social. Contudo, ainda que o medo de um Deus não tenha nada que o faça critério e fundamento de comportamentos políticos e sociais por si mesmo, pode tornar-se tal graças à intervenção prudente de um legislador que saiba alimentar, orientar e, sobretudo, organizar em instituições estáveis esse sentimento humano, tornando-o, assim, apto a suscitar coesão política e obediência civil." (AMES, 2006, p. 55).

${ }^{25}$ Contrato Social, livro II, capítulo 7.
} 
Maomé propuseram leis a seus povos, eles não estavam convocando os cidadãos a compor assembleias para deliberar racionalmente sobre a adequação delas ao bem público. Era impossível para essas nações incipientes fazer reflexões dessa espécie, uma vez que elas careciam do espírito social que lhes permitiria discernir o valor das boas instituições que lhes eram oferecidas. Restava ao legislador persuadir o povo sem convencê-lo, invocando o único argumento válido para os seus ouvidos, isto é, a autoridade divina.

Por outro lado, a concordância entre Maquiavel e Rousseau vai apenas até certo ponto, em se tratando do legislador. De acordo com o genebrino, essa figura é extraordinária não somente por sua sabedoria e seu desejo de promover o bem de um povo, mas igualmente porque sua condição dentro do Estado é impar. Para que não cometa abusos na aplicação das leis nem usurpe para si o direito de aprová-las, o qual pertence à vontade geral do conjunto dos cidadãos, o legislador não é magistrado nem soberano. Desse modo, sua tarefa implica duas coisas que, Rousseau (2003, p. 383, tradução nossa) ressalta, parecem incompatíveis e cuja coincidência é quase um milagre: "um empreendimento acima da força humana e, para executá-lo, uma autoridade que nada é." Isso ajuda a explicar por que, na visão do filósofo, existiram tão poucas repúblicas bem ordenadas na história, já que é raro encontrar as condições propícias ao trabalho do legislador.

Maquiavel também reconhece essa raridade, embora sua descrição do legislador divirja daquela presente no Contrato Social por causa do poder necessário, em sua concepção, a esse agente político. No sexto capítulo d'O Príncipe, por exemplo, ele enfatiza que os instituidores de novos ordenamentos e costumes que mais merecem louvores são personagens tais como Moisés, Ciro e Rômulo, príncipes dotados de enorme virtù e que receberam da fortuna somente a ocasião para agir. Contudo, eles não teriam sido bem sucedidos se não contassem com a força das armas para apoiar suas inovações, pois sempre é preciso superar as resistências tanto daqueles que se beneficiavam do antigo status quo quanto das pessoas que desconfiam daquilo que não conhecem. Por isso, explica Maquiavel (2011, p. 71-73):

Todos os profetas armados venceram e os desarmados se arruinaram. Porque [...] a natureza dos povos é variada e é fácil persuadi-los em uma coisa, mas é difícil sustentá-los nessa persuasão. E, porém, convém ser ordenado de modo que, quando não creem mais, se possa fazer com que creiam pela força.

Esse recurso à violência é algo que não se coaduna com a tese rousseauniana de que as leis devem ser aceitas voluntariamente pelo povo para serem legítimas. É para não empregar a força como meio de coação dos indivíduos que o legislador tem de utilizar uma linguagem persuasiva a fim de mobilizar as paixões humanas, o que caracteriza, nas palavras de Ericson Falabretti, "O emprego da retórica religiosa enquanto técnica argumentativa - canto civil", ou seja, "a forma melódica da linguagem capaz de superar os obstáculos, de desviar a política da violência física - da coerção pelas armas - e dirigir a vontade dos particulares aos interesses públicos." (FALABRETTI, 2011, p. 181). ${ }^{29}$ Maquiavel, contudo, não tem essa mesma preocupação. Dentro dos horizontes das relações efetivas de poder entre os homens, ele entende que a força é um meio

\footnotetext{
${ }^{29}$ Isto não quer dizer que, para Rousseau, o uso da força nunca seja necessário no interior do Estado. Apesar de estar excluído da relação entre o legislador e o soberano, ele se faz presente na atuação do governo. Como se vê no início do livro 3 do Contrato Social, o governo é um corpo intermediário entre o soberano e os súditos, cuja tarefa é aplicar a legislação nas situações concretas da administração pública; ou seja, trata-se do poder executivo que age em função do que foi fixado pelo poder legislativo (soberano). Neste sentido, o governo pode e deve empregar legitimamente a força depositada em suas mãos pelo povo para garantir o cumprimento da vontade geral e a preservação da ordem civil.
} 
amplamente utilizado e que não convém rejeitá-lo por considerações de ordem moral, religiosa ou mesmo política, desde que seja empregado de forma adequada aos desafios relativos ao estabelecimento e à manutenção da ordem pública. Isso fica bem claro nas páginas dos Discursos em que o autor afirma ser melhor que apenas um homem esteja à frente da tarefa de ordenar uma nova república ou reformar inteiramente uma antiga, sobretudo se for alguém prudente e de virtù, cujo desejo seja favorecer a pátria e o bem comum, e não somente a si mesmo e a seus descendentes. Tudo o que esse inovador fizer será justificado pelo sucesso de seu objetivo, incluindo o uso da força e até os assassinatos, "porque se deve repreender quem é violento para estragar, e não quem o é para consertar" (MAQUIAVEL, 2007, p. 41) ${ }^{30}$. Ademais, ainda que haja a necessidade dessa violência fundadora por parte do instituidor da república, Maquiavel explica que a manutenção desse corpo político será mais bem conduzida por muitas pessoas, uma vez que poucos indivíduos têm a sabedoria requerida para criar boas instituições, mas a maioria dos cidadãos é capaz de defender com afinco os bons ordenamentos que regem sua convivência.

Tal constatação aponta para um problema que se verifica em outro momento da história política de um povo, ou seja, aquele em que a corrupção se tornou uma moléstia tão grave que ameaça de morte o Estado. Na visão de Maquiavel, o melhor seria tomar medidas para evitar que a situação chegasse a essa gravidade, o que implicaria mudanças nos ordenamentos. Entretanto, a experiência revela que é muito difícil realizá-las a tempo, seja de uma só vez, seja aos poucos. A razão disso é que as reformas gradativas teriam de ser promovidas por um homem de grande virtù que tivesse a capacidade de prever os males futuros, e não apenas a aparição de tais indivíduos é incomum, como também é pouco provável que eles consigam convencer a maioria das pessoas sobre a necessidade de alterações no Estado por causa de problemas que ainda não se manifestaram totalmente. No caso de grandes reformas, quando a corrupção já se fez evidente para todos, os meios ordinários são inúteis e seria preciso que alguém adquirisse um poder principesco para impor mudanças por meios extraordinários, isto é, as armas. Esse quadro coloca um dilema aparentemente insolúvel:

Como a reordenação de uma cidade para a vida política pressupõe um homem bom, e tornar-se príncipe de uma república pela violência pressupõe um homem mau, ver-se-á que raríssimas vezes um homem bom queira tornar-se príncipe por vias más, ainda que o fim seja bom; e também é raro que um homem malvado, tornando-se príncipe, deseje bem obrar e que se lhe incuta no ânimo o bom uso da autoridade que conquistou por meios maus. (MAQUIAVEL, 2007, p. 75-76) ${ }^{31}$.

Assim, vê-se que Maquiavel reconhece no príncipe de virtù o sujeito necessário ao reordenamento de uma cidade corrompida, embora também admita o quão infrequente é encontrar um homem disposto a "sujar as mãos" para recolocar a república no caminho da liberdade.

A alusão à bondade e à maldade dos homens nos leva de volta às questões discutidas inicialmente e que estão no cerne da instituição política operada pelos legisladores. Ao abordar esse tema, Lionel A. McKenzie defende a tese de que as diferentes suposições sobre a natureza humana feitas por Maquiavel e Rousseau afetam crucialmente o modo como eles definem a tarefa dos legisladores, já que o primeiro teria partido da ideia de que todos os homens são maus, ao passo que o segundo acreditava que eles são potencialmente bons, embora a vida em sociedade os corrompa. Então, escreve McKenzie (1982, p. 224, tradução nossa):

\footnotetext{
30 Primeira Parte, capítulo 9.

${ }^{31}$ Discursos, Primeira Parte, capítulo 18.
} 


\begin{abstract}
Esse é, provavelmente, o núcleo de seu desacordo e do qual outras diferenças se seguiram. O legislador de Maquiavel tem que tomar precauções contra a natureza má do homem. Equilibrando o autointeresse e a ambição de uma classe ou grupo contra os de outro, o legislador poderia assegurar algum bem duradouro para a sociedade que ele estabeleceu. O legislador de Rousseau, em contrapartida, estabeleceu as condições que permitiriam aos homens realizarem seu potencial completo para o bem na sociedade civil, para cada um se tornar "um ser inteligente e um homem."
\end{abstract}

Por seu caráter sintético, essas observações acabam simplificando as posições de Maquiavel e de Rousseau. Afinal, como vimos, ambos reconhecem que o bem e o mal perpassam as relações sociopolíticas e que a vida republicana é capaz de enobrecer a conduta humana e fomentar a virtude cívica. Conforme escreve Newton Bignotto (1991, p. 86) a respeito de Maquiavel, a novidade contida em suas obras:

Não é a afirmação da maldade dos homens, mas a de que essa maldade não impede a criação de instituições boas. Mais radicalmente ainda, podemos dizer que é da propensão ao conflito que nasce a possibilidade da liberdade. A liberdade é, portanto, o resultado dos conflitos, uma solução possível de uma luta que não pode ser extinta por nenhuma criação humana. De uma problemática antropológica passamos a conceber a política como uma forma de guerra. Mas a guerra não significa aqui a pura negatividade, ela aponta para o verdadeiro ponto de partida de toda reflexão sobre a política, que é a existência dos desejos opostos na "polis".

Diante dessas observações sobre o conflito político e a liberdade republicana, chegamos a um tópico fundamental para a compreensão das ideias de Maquiavel e, por contraste, também para o entendimento das teses de Rousseau. Trata-se de um problema complexo sobre o qual farei aqui somente alguns apontamentos bastante breves ${ }^{32}$.

Nos Discursos, Maquiavel começa a apresentar sua tese sobre a importância da desunião entre a plebe e o senado como causa do sucesso político de Roma ao ressaltar que, apesar de os ordenamentos da cidade não terem sido produzidos de uma só vez por um legislador dotado de grande virtù, os eventos ocorridos ao longo de sua história foram responsáveis por gerar boas leis. Se Roma não teve a fortuna inicial em sua fundação, ainda assim contou com a fortuna na sequência, e a virtù de seus cidadãos Ihes permitiu suprir as insuficiências de origem. Isso porque Rômulo e seus sucessores instituíram boas leis voltadas à liberdade, mas adequadas a um reino, e quando Roma transformou-se em república, foi preciso criar novas coisas propícias à liberdade. Avaliando como se deu esse processo, Maquiavel (2007, p. 21-22) ${ }^{33}$ escreve:

Direi que quem condena os tumultos entre os nobres e a plebe parece censurar as coisas que foram a causa primeira da liberdade de Roma e considerar mais as assuadas e a grita que de tais tumultos nasciam do que os bons efeitos que eles geravam; e não consideram que em toda república há dois humores diferentes, o do povo, e o dos grandes; e que todas as leis que se fazem em favor da liberdade nascem da desunião deles, como facilmente se pode ver que ocorreu em Roma.

\footnotetext{
${ }^{32}$ Este tema dos conflitos sociais como elemento favorável ou não à liberdade política nas perspectivas de Maquiavel e de Rousseau foi discutido mais detalhadamente no trabalho apresentado por mim em uma mesa redonda durante o VI Colóquio Internacional Rousseau, ocorrido em Pirenópolis - GO em junho de 2013. O artigo resultante dessa apresentação foi publicado pela revista Trans/form/ação. (MOSCATELI, 2015).

${ }^{33}$ Discursos, Primeira Parte, capítulo 4.
} 
A teoria de Maquiavel sobre os "humores" é importante para entendermos sua concepção de política em geral e remete à discussão feita inicialmente a respeito dos desejos que movem os homens. Ela começa a ser apresentada no capítulo 9 d'O Príncipe, no qual o autor explica que o povo tem o desejo de não ser governado nem oprimido pelos grandes, ao passo que estes são movidos pelo desejo de governar e oprimir o povo. Nessa perspectiva, Maquiavel interpretou as dissensões entre os patrícios e os plebeus como algo que contribuiu para o aperfeiçoamento e a estabilidade da república romana por muitos séculos. Como se tratava de um corpo político bem ordenado, cujos cidadãos possuíam uma grande virtù nascida da boa educação, os tumultos eram capazes de dar origem às leis garantidoras da liberdade, pois os excessos que surgiam do desejo de uma das partes da sociedade acabavam sendo confrontados pelo desejo oposto da outra parte, como se vê nas análises feitas por Maquiavel de diversos episódios da história de Roma. Ademais, tais confrontos se davam dentro dos ordenamentos da república, sem que se precisasse recorrer a meios violentos para a sua resolução. Dessa forma, fica claro que Maquiavel compreende a esfera política como sendo atravessada por relações de forças entre os diferentes grupos sociais, relações que se modificam no decorrer do tempo em função das possibilidades concretas de manifestação dos humores heterogêneos, o que leva a equilíbrios sempre transitórios entre as demandas de cada participante do confronto.

No tocante às propostas políticas de Rousseau, por outro lado, sua ênfase está muito menos nos conflitos como fator favorável ao bom ordenamento republicano, e muito mais na união das vontades dos cidadãos como requisito imprescindível a um Estado onde a liberdade seja viável. Ainda que o próprio Rousseau tenha tentado, em vários pontos do Contrato Social, aproximar suas ideias políticas das teses de Maquiavel acerca dos conflitos, seria inapropriado desconsiderar suas diferenças ${ }^{34}$. Para citar apenas um excerto que é um dos melhores para visualizá-las, encontramos uma síntese do ideal republicano de Rousseau (2003, p. 437, tradução nossa) ${ }^{35}$ na proposição de que:

Enquanto muitos homens reunidos se consideram como um só corpo, eles têm uma única vontade que se refere à conservação comum e ao bem-estar geral. Então, todos os móveis do Estado são vigorosos e simples, suas máximas são claras e luminosas, não há interesses confusos e contraditórios, o bem comum mostra-se por toda parte com evidência e exige apenas bom senso para ser percebido.

Em uma comunidade na qual se manifestasse essa expressiva confluência das vontades individuais em direção à vontade geral, o filósofo acredita que poucas leis bastariam para governar o povo, e todas as vezes que alguma mudança fosse necessária, os cidadãos sentiriam isso facilmente e o acordo nas deliberações passaria longe das intrigas e dos duelos de eloquência ${ }^{36}$. Sem dúvida, esse quadro descreve o que se poderia ver como o grau máximo de unidade civil, o ponto

\footnotetext{
${ }^{34}$ Ver o livro II, capítulo 3; o livro III, capítulos 9 e 10; o livro IV, capítulo 2.

${ }^{35}$ Contrato Social, livro IV, capítulo 1.

${ }^{36}$ De acordo com Claudio Araujo Reis (2010, p. 23), "O processo deliberativo, segundo Rousseau, é menos uma troca pública e coletiva de razões e argumentações do que uma consulta individual à consciência. Ouvir a voz da consciência, que é um sentimento e está sempre voltada para o bem, é o ponto fundamental. Lembremos que mais de uma vez Rousseau explicita sua falta de gosto pelos debates, pelas discussões públicas. O processo pelo qual se chega à declaração da vontade geral (pelo qual tomamos uma decisão coletiva) não é essencialmente um processo de troca de razões nem, muito menos, um processo de barganha, de negociação, de acomodação de interesses (o que tende, como bem viu Rousseau, a ser agravado por uma política de facções, de partidos, que fatalmente dirigem o jogo político em direção à competição e não à cooperação)."
} 
mais alto na escala dos princípios do direito político contidos na obra de Rousseau, um extremo de perfeição que os Estados concretos jamais alcançariam. Afinal, a ordem social é fruto de um artifício gerado por convenções humanas e sempre terá limitações práticas em seu estabelecimento, como o próprio autor reconheceu: "Tudo o que não está na natureza tem seus inconvenientes, e a sociedade civil mais do que todo o resto" (ROUSSEAU, 2003, p. 431, tradução nossa) ${ }^{37}$. Porém, ainda assim essa imagem de comunhão entre os membros do pacto social é um parâmetro fundamental para se julgar a qualidade das práticas políticas de quaisquer Estados. Quanto mais elas se afastam do padrão de referência, menores são as chances de que se tenha uma república bem ordenada, como Rousseau deixa claro ao criticar os males advindos do afrouxamento dos laços sociais. Na medida em que a união do Estado se enfraquece, os interesses particulares tornam-se influentes e as pequenas associações - isto é, as facções ou associações parciais - interferem cada vez mais nos rumos tomados pela comunidade, de forma que "o interesse comum se altera e encontra opositores, a unanimidade não reina mais nos votos, a vontade geral não é mais a vontade de todos, surgem contradições, debates, e a melhor opinião não é aprovada sem disputas" (ROUSSEAU, 2003, p. 438, tradução nossa).

Enfim, antes de concluir, é importante dizer que, assim como Maquiavel não era ingênuo a ponto de crer que todos os conflitos políticos resultavam em benefícios para a república ${ }^{38}$, Rousseau também reconheceu que, além da concórdia reinante em um Estado bem ordenado, há aquela que se impõe por meio da força de um governo autoritário usurpador da soberania popular. Basta lembrar a conclusão do Segundo Discurso, obra que contrapõe a igualdade natural dos indivíduos antes do estabelecimento das sociedades, por um lado, ao grau último da desigualdade que se atinge sob o despotismo, por outro, onde "todos os particulares se tornam iguais porque não são nada e os súditos não têm outra lei exceto a vontade do senhor" (ROUSSEAU, 2003, p. 190, tradução nossa). Trata-se aí de uma condição de extrema opressão radicalmente oposta ao anseio pela vida livre, para o qual tanto Rousseau quanto Maquiavel dedicaram grande parte de suas reflexões. Mesmo que suas respectivas doutrinas políticas tenham divergido em pontos importantes, ao se alinharem à tradição republicana ambos buscaram, cada qual a seu modo, valorizá-la como fonte de inspiração para formas de cidadania mais efetivas, deixando assim um rico legado capaz de auxiliar nossos próprios esforços para repensar os rumos da política como sujeitos do séc. $\mathrm{XXI}$.

\footnotetext{
${ }^{37}$ Contrato Social, livro III, capítulo 15

${ }^{38}$ De fato, o autor mostra que há conflitos que se manifestam de modo contrário à preservação da ordem e da liberdade republicanas, sobretudo quando se atenta para as causas que levaram aos abusos cometidos pelos decênviros romanos (ver os Discursos, Primeira Parte, capítulos 35 e 40), bem como para as guerras civis que levaram ao fim da república no séc. I a.C. (ver os Discursos, Primeira Parte, capítulos 37).
} 


\section{Referências}

ADVERSE, H. Maquiavel, a república e o desejo de liberdade. Trans/Form/Ação, São Paulo, v. 30, n. 2, p. 33-52, 2007.

AMES, J. L. Religião e política no pensamento de Maquiavel. Kriterion, Belo Horizonte, n. 113, p. 51-72, jun. 2006.

. Maquiavel e a educação: a formação do bom cidadão. Trans/Form/Ação, São Paulo, v. 31, n. 2, p. 137-152, 2008.

BIGNOTTO, N. Maquiavel republicano. São Paulo: Loyola, 1991.

A antropologia negativa de Maquiavel. Analytica, Rio de Janeiro, v. 12, n. 2, p. 77-100, 2008.

FALABRETTI, E. A linguística de Rousseau: estrutura aberta e potência criadora da linguagem. Analytica, Rio de Janeiro, v. 15, n. 2, p. 147-198, 2011.

MAQUIAVEL, N. Discursos sobre a primeira década de Tito Lívio. Tradução MF. São Paulo: Martins Fontes, 2007.

História de Florença. 2. ed. Tradução Nelson Canabarro. São Paulo: Musa, 1998.

. O Príncipe. Tradução José Antônio Martins.

São Paulo: Hedra, 2011.

MCKENZIE, L. A. Rousseau's debate with Machiavelli in the Social Contract. Journal of the History of Ideas, v. 43, n. 2, p. 209-228, abr.-jun. 1982.
MOSCATELI, R. Maquiavel versus Rousseau: as divisões sociais e seu papel em uma república bem-ordenada. Trans/form/ação, Marília, v. 38, p. 121-138, 2015. Edição especial.

POCOCK, J. G. A. El momento maquiavélico: el pensamiento político florentino y la tradición republicana atlántica. Tradução Marta Vásquez-Pimentel e Eloy García. Madri: Tecnos, 2008.

REIS, C. A. Vontade geral e decisão coletiva em Rousseau. Trans/Form/Ação, Marília, v. 33, n. 2, p.11-34, 2010.

ROUSSEAU, J.-J. CEuvres complètes. Paris: Gallimard, 2003. v. 3

CEuvres complètes. Paris: Gallimard, 1980. v.

$\overline{4}$.

SKINNER, Q. Maquiavel. Tradução Maria Lucia Montes. São Paulo: Brasiliense, 1988.

STAROBINSKI, J. Jean-Jacques Rousseau: a transparência e o obstáculo. Tradução Maria L. Machado. São Paulo: Companhia das Letras, 1991.

VIROLI, M. Jean-Jacques Rousseau and the "well-ordered society". Tradução Derek Hanson. Cambridge: Cambridge University Press, 2002. 